plete than formerly, but along the southern side alone there were at least ten quite recognizable by the craters and by the fire-reddened stones with which they had been lined, though only rarely was a part of the lining standing. As to stones, Millstone Grit was the chief constituent, black chert, often crinoidal, was quite common, but Carboniferous limestone was very rare except about the tops of the kilns, where pebbles were freely scattered. Bits of good coal could also be found near the pits. The general appearance of the Delves is very striking and-pace Professor Gregory-unmistakable; for the whole length of the ridge the form is quite obviously artificial-dimples, craters, and trenches everywhere modify the surface, one great trench runs for scores of yards parallel with the northern margin. On the south side spurs project, often with the crater of a lime-kiln. I confirmed my earlier impression that not a yard of the original form was preserved.

There is a small isolated knoll, "Little Skirtfull of Stones," consisting wholly of cobble-stones without infilling; this I regard as a cairn-probably prehistoric-and not a moraine mound.

P. F. Kendall.

\title{
CARBONIFEROUS NOMENCLATURE.
}

SIR,-All geologists, and particularly those connected with Carboniferous geology, are grateful to Dr. R. Kidston for replacing the old and provincial subdivisions of the Coal Measures by terms of correlative value, dependent on their floras as worked out by himsclf, Arber, and other palæobotanists. The words Lanarkian and Staffordian are both precise and euphonious, Radstockian at least precise and indicative. The fourth term, Westphalian, however, is not only " unconformable" to the others in having no "local habitation" in this country, but differs in spirit from the rest in that it seems to suggest that these, our richest measures, are not typically represented in Britain. Worse than this, the term has been preoccupied since 1893, when Munier-Chalmas and de Lapparent used the word in a wider sense, equivalent to the whole of Kidston's three lowest divisions. If, as seems advisable, the use of the term Westphalian in the restricted sense is abandoned, it would be difficult to select one more representative than "Yorkian", particularly as its only likely rival "Lancastrian" may conceivably be wanted in the end for another Carboniferous subdivision.

IMPertal. College, S.W. 7.

W. W. Watts.

8th March, 1922.

THE STRATIGRAPHICAL VALUE OF FORAMINIFERA.

Sin,--In view of the interest now displayed in the possibility of utilising the foraminifera associated with oil deposits as zonal fossils, 
a recent paper by Dr. Rufus M. Bagg ${ }^{1}$ is rather a shock. Dr. Bagg has examined thin slices of chert from the Bonaventure conglomerate and gives a list of forty-four species and one variety of foraminifera which he has determined; and he concludes that the cherts are of either Cambrian or early Ordovician age and prohably the latter. Yet, of the forty-five kinds, no less than thirty-seven are recorded by Brady $^{2}$ as still living! One other is reported as recent by d'Orbigny. ${ }^{3}$ Of the thirty-eight one only, according to Brady, may go back to the Silurian and that is doubtfully the same, for it is the simplest type of hyaline foraminifer known (Lagena globosa), a simple spheroid. Of the thirty-eight living forms two go back to the Permian and Carboniferous, and these are also simple and doubtful species (Nodosaria comminnis and $N$. radicula); eighteen are known first in the Trias; three others are known first in the Jurassic; and four others first from the Cretaceous. The whole thirty-eight living forms are also recorded from Tertiary strata.

Why, then, is this collection of foraminifera described as early Paleozoic? There are no fossils other than foraminifera recognisable specifically. The author apparently relies mainly on some foraminifera found in Cambrian rocks of New Brunswick, and described by G. F. Matthew. ${ }^{4}$ of these Dr. Bagg finds at. Gaspé, Globigerina cambrica Matthew, G. didyma Matthew, and Orbulina ovalis Matthew. 'The author's figure of $G$. cambrica does not agree with Matthew's, while that of $G$. didyma might belong to many kinds of foraminifera. Dr. Bagg himself throws doubt on the separate existence of such subspecies as Globigerina cretacea or Orbulina ovalia (p. 38, reprint), and none of the determinations is free from doubt. His figure of Orbulina ovalis would do for a simple Lagena. Of the other four forms not now living, two are Tertiary and one of these has also been recorded by Brady as Permian and Carboniferous; the other two are Cretaceons species, but one has been described by Ehrenberg as early Palæozoic also.

It is interesting to note that, although Dr. Bagg gives a list of forty-four species and one variety, without any name being queried (three have wrong authors assigned), yet in no less than thirty-five cases, more or less doubt is expressed in the paper as to the correct determination. Thus, Bolivina reticulata Hantken, listed on p. 47 (reprint) as definitely identified, is deseribed on p. 22 as follows :"Bolivina sp. . . . perhaps $B$. reliculata Hantken Plate 3, figures 5-7.

On slide 6 (see figure 5), near the northeast corner, is a cross section of Bolivina which has five widely inflated segments in each

1 "The Foraminifera of the Bonaventure Cherts of Gaspé": N.Y. State Museum Bull. No. 219, 220. Fifteenth Report of the Director, 1918, 1921.

2 Reports of the Scientific Results of the Voyage of H.M.S. Challenger, vol. ix (7.oology), 4to, London, 1884.

3 Foraminifères fossiles du Bassin tertiaire de Vienne, 4to., Paris, I846.

4 "The Protolenus Fauna": Trans. N.Y. Acad. Sciences, vol. xiv, 1895, pp. 101-53. 
series, strongly overlapping and highly arched on their extremity, so that the outline closely resembles Bolivina reticulata Hantken, but also Bolivina dilatata Reuss, though both of these species have more chambers in each series than does the present type. We are inclined to think that this is a new species of Bolivina, though it may be a variety of either of the above. We shall consider it, however, a variety of $B$. reticulata as the reticulate surface might not show in cross section. In length the specimen measures $0.26 \mathrm{~mm}$."

Here we see a very considerable uncertainty as to the determination of the species.

We may safely say that the evidence from the foraminifera is in favour of the chert in which they occur being, at earliest, Mesozoic. Dr. Bagg himself remarks that, taken as a whole, the fauna is more like that of the Trias than of the older Palæozoic (p. 8). He bas apparently started with the assumption that the chert must be Older Palæozoic, thus (p. 8) he writes: "We do not know of any such discovery in formations so primitive as these must be, and did not suppose that Virgulina occurred in Palrozoic horizons." One does not know the strength of the evidence for this assumption. It is, however, curions that, according to the description of Dr. John M. Clarke in the Guide Book to the Congrés Géologique International (Guide Book No. 1, pt. i, 1913, p. 91, and map opposite p. 88, 1913), the Bonaventure conglomerate lies almost horizontally and is unconformable to all other rocks in Gaspé. One wonders if the conglomerate is really as old as is supposed. There are but three possibilities-(1) that many of the foraminifera have been wrongly determined, (2) that the Bonaventure conglomerate is not older than Mesozoic, (3) that foraminifera are quite useless for stratigraphical purposes. Which of these possibilities are true perhaps time will show.

Arril, 1929.

R. L. Sherlock.

\section{ANNOUNCEMENTS AND INQUIRIES.}

Mr. W. Whitaker, F.R.S., would be glad to have information concerning the Water Supply of Dorset, for use in a Memoir of the Geological Survey, now in preparation. Accounts of wells, springs, mineral waters, water analyses, etc., will be acceptable. The contents of journals of wide circulation, and of well-established local periodicals, such as the Proceedings of the Dorset Field Club, are already available to him, but he believes that there exist many little-known provincially published works, as well as a large mass of unpublished information, that would be very useful.

New address: Wellesley Court, Wellesley Road, Croydon. 